\title{
Reporting and Interviewing Styles of Professional and Citizen Reporters on Periscope
}

\author{
Karadağ G.H. ${ }^{1}$ \\ ${ }^{1}$ Gökmen Hakan KARADAĞ, Istanbul Aydin University, (Turkey) \\ e-mail: gokmenkaradag@aydin.edu.tr
}

\begin{abstract}
Live broadcast, being in the monopoly of the traditional media in the past, has become a broadcasting opportunity accessible to much more people thanks to the developing digital technology nowadays. This opportunity is even available to anybody using a cellular phone through applications that make live streaming possible by a single touch. Periscope, which is a mobile live streaming application, is one of them. This study aims to identify, classify and reveal the properties of various reporting and interviewing styles in the new media by conducting the quantitative, qualitative and discourse analysis of the live streaming of the professional and citizen reporters on Periscope. Thus, also the answer to the question, whether the content produced on Periscope is in compliance with the format of that medium is investigated. In this study, it has been questioned what the data at hand points for facilitating the professionals, who use Periscope independently from their roles within the conventional media or as a complementary to their roles in the conventional media and the citizens, who use it for journalistic purposes to create an effective alternative in this new platform.
\end{abstract}

Keywords: traditional media, new media, social media, live streaming, Periscope, citizen journalism

\section{Introduction}

Unlike the traditional media (books, television and radio), the term "new media" is used to describe the digital media, especially the interactional media, internet networks and social communication media (Binark, 2014). Every novel communication technology develops some new practices for production, consumption and use, while benefiting from the environment and cultural practices in which the previous technologies flourished (Binark, 2015: 10). Through the communication tools that we use, the individual becomes a reader with the newspaper; a viewer with the television; a user with the internet; an interactive user with the applications (Yengin, 2014: 160). While the rapidly developing digital technology equips the media constantly with new means, the content production and consumption processes transform into completely different forms than the traditional media forms.

Even the words "production" and "consumption" are considered as the terms of the conventional media and new terms are generated to express the difference and specificity of the new media. Bruns has suggested "produsage" as an alternative term for user-led environments and defined produsage as "the collaborative and continuous building and extending of existing content in pursuit of further improvement" (Jenkins, 2008). For Rosen, the people formerly known as the audience are those who were on the receiving end of a media system that ran one way, in a broadcasting pattern, with high entry fees and a few firms competing to speak very loudly while the rest of the population listened in isolation from one another and who today are not in a situation like that at all (Rosen, 2011).

Technological change exerts a profound influence on journalism in at least four ways: (1) how journalists do their job; (2) the content of news: (3) the structure of the newsroom and the news industry: and (4) the relationship between news organizations and their publics (Pavlik, 2000: 236). In order to define the 
changes that the technology gave rise in the practices of journalism, new definitions such as "video journalism", "mobile journalism" and "multimedia journalism" have been introduced. The term "videojournalism" originally emerged to describe a style of filming where a journalist used a small lightweight video camera to single-handedly film and report a story, instead of working with a crew consisting of a cameraperson, soundperson and even lighting technician (Morgan, 2008: 1). When video journalism met the mobile technology, this time the term mobile journalism was born. Mobile journalists are journalists who work alone in the field using mobile phones for newsgathering (Karhunen, 2017: 6). Deuze, who offers a pragmatic, contemporary definition of multimedia journalism, characterized two features of this new practice: the presentation of a news story package on a website using two or more media formats and the integrated presentation of a news story package through different media (Deuze 2004: 140).

Besides the means provided to the professional journalists, the practices of video journalism, mobile journalism or multimedia journalism facilitates the participation of the citizens in the production of contents as well as. The shift from an era of broadcast mass media to an era of networked digital media has transferred the means of media production and dissemination into the hands of the public. For some, the consequences of this shift raised questions about who can be described as a journalist and perhaps, even, how journalism itself is defined (Hermida, 2010). Positioning of journalism as a profession differs from some other established professions, and this is a feature that holds the doors open to the citizen journalists. According to Godkin, unlike established professions such as law, medicine or accounting any standard of journalistic competency must be centred on practice rather than theory (Godkin, 2008: 110). For example, for anyone contemplating a career in journalism, familiarity in the use of computer technology and a capacity to make creative use of the Internet are as central as the use of a typewriter was previously (Dahlgren, 1996: 60). The positioning of a professional journalist who cannot keep up with the evolving digital technology and a citizen journalist who adopted this technology very well and uses in a creative way will be different in conventional media and new media.

The facilitation of the digital technology to produce content, has paved the way for citizen journalists. The things that could only be done by a conventional media professional, can be done by a citizen reporter or even a user in the new media now thanks to digital technology. For example, live broadcast. This property, which used to be a cult in conventional television broadcasting is now in the hands of everyone thanks to the Periscope, which is a mobile application allowing live streaming very simply. The limitations in the contents of the conventional media, which used to take part in the daily lives of individuals, presentation techniques, time and space dependencies diminish in the new media as if they have been exposed to the light of a magical torch (Şahin \& Şahin, 2016: 61). Journalism, which was once difficult and expensive to produce, today surrounds us like the air we breathe. Much of it is, literally, ambient, and being produced by professionals and citizens (Hermida, 2010).

The term "live streaming" in new media has become the counterpart of the term "live broadcast" in traditional media. Live streaming became a popular concept in the realms of new media and citizen journalism after the launch of Periscope and Meerkat, however their predecessors emerged in 2007. Both Livestream and Ustream were launched in 2007. Before Periscope, Millions used Twitch to watch other people play videogames, YouTube, Ustream and a dozen others have tried to make businesses out of live streaming video but Periscope is like the right platform and the right time (Pearce, 2015). Live streaming applications are nothing new but as smartphone cameras and internet connectivity have increased, as have the possibilities to broadcast straight from mobile (Reid, 2015). Although "broadcast" is a term used mostly in traditional media, it is used throughout this paper as Periscope application itself refers to live streams of users as "broadcast".

This study aims to identify, classify and reveal the properties of various reporting and interviewing styles in the new media by conducting the quantitative, qualitative and discourse analysis of the live streaming of the professional and citizen reporters on Periscope. It has been also questioned, whether the content produced on Periscope is in compliance with the format of that medium. Such studies are important not only for the professionals, who use Periscope independently from their roles within the conventional media or as a complementary to their roles in the conventional media, but also for the citizens, who use it for journalistic purposes to create an effective alternative in this new platform. 
By the way, Twitter, the owner of Periscope, had to change the name of the application in Turkey to "Scope" on March 31, 2017 due to the complaint of a Turkish company. The "Periskop Communications and Production Services" company in Turkey sued Periscope for violating its trademark rights. The court's decision was to halt Periscope. Twitter changed the name of Periscope to keep the availability of its application while announcing that it would continue to seek its rights. However, as the sample study in this paper was carried out in 2016, the application is referred to as "Periscope" not "Scope" throughout the paper.

\section{Methodology}

This study, aiming to identify, classify and reveal the properties of the different reporting and interviewing styles of the professional and citizen reporters in their Periscope broadcasts, is a continuation of my previous work. I had reviewed the possibilities that Periscope offer the professional reporters and citizen reporters in an earlier study (Karadağ, 2017). I had drawn conclusions from the sample I used there through quantitative analysis method. Quantitative analysis takes place in this study as well, but this time I draw conclusions in terms of broadcast styles on Periscope by using qualitative analysis and discourse analysis of the same sample.

A one-month period was selected for this analysis: Feb 16 - March 17, 2016. However, the sampling studies started at an earlier date, around early February 2016. Professional reporters to be included in the sample was restricted to the number of followers they had. Journalists with more than 12,000 Periscope followers were observed. 30 journalists were selected this way and they were listed by their follower numbers. TV anchorman Fatih Portakal with 182,758 Periscope followers (3.77 million Twitter followers) ranked first in the list while journalist Metehan Demir with 13,088 Periscope followers ranked last.

However, during the preliminary studies, it was observed that an analysis based solely on the criteria of follower numbers would not be sufficient in revealing Periscope's true potential. This is due to the presence of journalists having large numbers of followers yet not broadcasting on Periscope and journalists using it effectively although they have less followers. Thus, during the preliminary studies which were carried out for shaping the sample, only 7 people from a list of 30 had broadcast on Periscope. This is the reason why professional reporters who do not meet the 12,000 follower criteria but use Periscope regularly as well as accounts which regularly perform citizen journalism on social media during the events with insufficient coverage by the mainstream media in Turkey were also included in the sample.

Two citizen reporters who live streamed highly watched broadcasts during the most dramatic incident took place within the observation period, the blast in Ankara's Kızılay Square, were also taken into consideration. So, a sample composing of a total of 40 professional and citizen reporter accounts was created and 121 broadcasts by these users in a one-month period (Feb 16-March 17, 2016) were included in the research. Records of these broadcasts were kept including following information: User, Periscope ID, Name of Broadcast, Date, Starting Time, Duration, Number of Live Audience, Number of Replay Audience, Number of Total Audience. In addition, also the following records have been kept for qualitative and discourse analysis: the subject of broadcast, (if any) interviewees of broadcast, (if live stand-up available) ad-libbing of reporters.

\section{Results}

The results of my previous study on Periscope can be summarized as follows:

The average audience statistics of both professional and citizen reporters in Turkey, which ranks second in the world after the U.S. in terms of Periscope usage, did not indicate a big potential as an alternative media. However, when the broadcasts in the sample were categorized into By Professional (BP) / By Citizen (BC); Inside (I) / Outside (O); News (N) / Non-News (NN); Breaking (B) / Non-Breaking (NB); Old Media Format (OM) / New Media Format (NM), and the statistics in these categories were evaluated, significant conclusions were drawn regarding the potential offered by Periscope. The substantial difference between the weights of different broadcast types in total duration of broadcasts

DOI NO: 10.7456/ctc_2017_07

(C) İstanbul Aydın University (c) Edlearning.it . AY11F0000 
and in total audience of broadcasts gave clues about which broadcasts draw more interest. Considered from this aspect and in light of this research it is seen that outside broadcast rather than inside broadcast, news purpose broadcast rather than non-news broadcast, breaking broadcast rather than non-breaking broadcast, and new media format broadcast rather than old media format broadcast attracts more audience. New media format broadcasts, with only $21 \%$ of the total duration of broadcasts in the sample, attracted $68 \%$ of total audience in the sample of this broadcast type. These data point out that in a new medium, content in new media format receives a much higher rating than traditional media format (Karadağ, 2017: 725).

Whereas in this study, the research was moved one step ahead and 121 broadcasts in the sample have been reviewed in terms of reporting and interviewing styles. As a result of the review, the Periscope usage types of the professionals and citizens may be classified as follows:

- Use of Periscope for Regular Studio Interviews

- Use of Periscope for Regular Commentaries

- Use of Periscope for Behind the Camera

- Use of Periscope for Live Reporting

- Use of Periscope for Breaking News

These topics have been addressed one by one in the article and both the usage types in the sample and the potentials for more effective use are detailed.

\section{Use of Periscope for Regular Studio Interviews}

Regular content production is crucial for the regular content audience in new media. There are two users producing regular content in sample: Journalists Rusen Çakır and Ünsal Ünlü. Rusen Çakır interviews with his guests in a semi-professional studio on weekdays, but these interviewees usually do not find a place in the mainstream media and Çakır discusses topics that are not addressed much in the mainstream media.

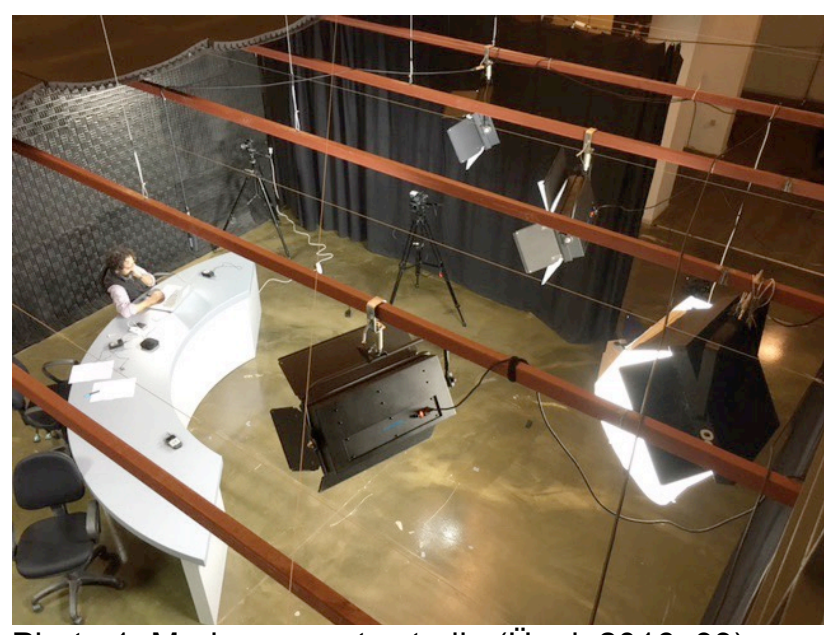

Photo 1. Medyascope.tv studio (Ünal, 2016: 93)

The broadcasts of Ruşen Çakır are uploaded also to Medyascope.tv site and together with the Periscope broadcasts of other volunteer journalists, Medyascope functions as an alternative media in Turkey. However, Ruşen Çakır opposes the identification of Medyascope as an activist or opponent media, and emphasizes that they are not different from any mainstream media enterprise or a news channel, trying to generate revenue (Ünal, 2017: 103). Indeed, Periscope broadcasts of Ruşen Çakır and his colleagues are more in the old media format rather than being in new media format. As with conventional media, Ruşen Çakır makes interviews in a studio with a seating arrangement and recorded by multiple cameras, 
and as with conventional media again, headlines and news ticker (scrolling text running from right to left) take place at the bottom of the screen.

In my previous study, Periscope broadcast were classified as Old Media Format and New Media Formats. Periscope broadcasts resembling traditional TV broadcasts were coded as "Old Media Format". These included mostly the broadcasts streamed sitting at a table in a studio, as longer forms of news talks or in a room as single commentary and longer form broadcasts. Broadcasts apart from these were coded as "New Media Format". Such broadcasts were usually outside broadcasts in shorter forms, moving formats where reporters move during the broadcast or "just live" broadcasts where reporters demonstrate the scene without giving any information. (Karadağ, 2017: 716) In the new media, the videos are viewed more in mobile viewing and the short form videos are viewed more rather than the long form and thus, audience potential of old media format broadcast will be lower. However, Ruşen Çakır and colleagues persistently continuing their broadcasting, not giving up the regular content production and broadcasting with the topics and guests that are not handled in the mainstream media (or with the questions not asked in the mainstream media) brought them "the 2016 Free Media Pioneer Award" of The International Press Institute (IPI Q \& A with Ruşen Çakır of Turkey's Medyascope.tv, 2016).

During the period between Feb 16 - March 17, 2016, when the sample had been observed, the total duration of the broadcasts of Ruşen Çakır was 701 minutes and these broadcasts have been watched by 41227 people, including the live audience and replay audience. Although rating is a concept of the conventional media, it may be adapted in such studies as the number of audience per minute. The ratings of the broadcasts of Ruşen Çakır within one month are shown in Graph 1.

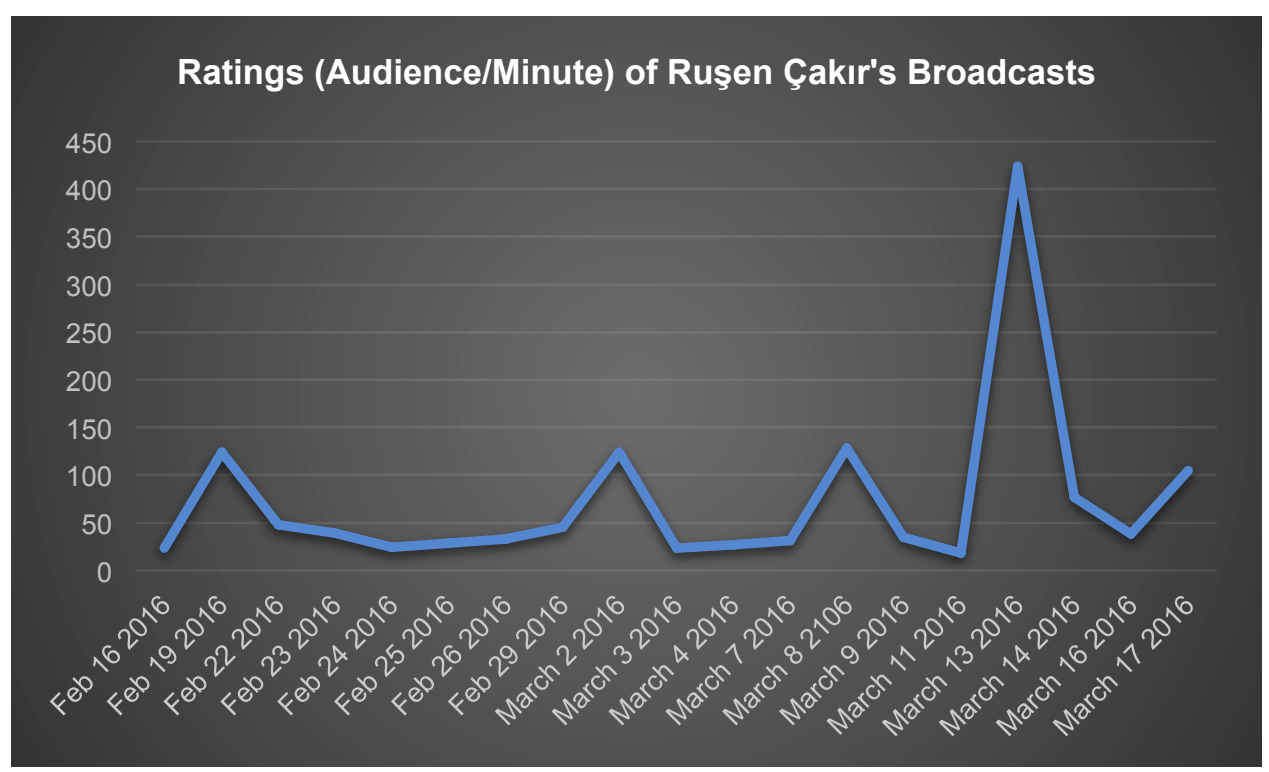

Graph 1. Total audience/minute ratings of Ruşen Çakır's broadcasts

When looking at the Graph 1, it can be seen that the broadcast of Ruşen Çakır with the highest rating was dated March 13, 2016. As the average audience/minute of Çakır was 59, in the broadcast on March 13, 2016, this figure was 424, that is the average rating was increased by about 7 times. Ruşen Çakır made this broadcast on March 13 2016, in the evening time, at 22:20, just a few hours after the terrorist attack in Ankara Kızılay and tagged the broadcast with the expression "about Ankara Kizilay attack". When looking at the Graph 1, the broadcasts forming the peak within 5 days are shown in the Table 1.

\begin{tabular}{|l|l|l|l|l|l|l|l|}
\hline Name of Broadcast & Date & Time & Dur & $\begin{array}{l}\text { Live } \\
\text { Aud }\end{array}$ & $\begin{array}{l}\text { Replay } \\
\text { Aud }\end{array}$ & $\begin{array}{l}\text { Total } \\
\text { Aud }\end{array}$ & $\begin{array}{l}\text { Total } \\
\text { Aud/Min }\end{array}$ \\
\hline
\end{tabular}




\begin{tabular}{|c|c|c|c|c|c|c|c|}
\hline $\begin{array}{l}\text { Ankara Kızılay saldırısı üzerine (About } \\
\text { Ankara Kizilay attack) }\end{array}$ & Mar 13 & $22: 20$ & 11 & 2608 & 2059 & 4667 & 424 \\
\hline $\begin{array}{l}\text { Hüseyin Çelik ile özel Skype yayını } \\
\text { (Special Skype interview with Hüseyin } \\
\text { Çelik) }\end{array}$ & Mar 8 & $17: 00$ & 48 & 4593 & 1534 & 6127 & 128 \\
\hline $\begin{array}{l}\text { Amberin Zaman ile Suriye'de neler } \\
\text { oluyor? (What's happening in Syria? With } \\
\text { Amberin Zaman) }\end{array}$ & Feb 19 & $16: 43$ & 18 & 1090 & 329 & 1419 & 124 \\
\hline $\begin{array}{l}\text { Ankara saldırısı Washington'da nasıl } \\
\text { yorumlanıyor? (How is Ankara attack } \\
\text { being interpreted in Washington?) }\end{array}$ & & $18: 04$ & 13 & 360 & 350 & 710 & \\
\hline $\begin{array}{l}\text { TAK (Kürdistan Özgürlük Şahinleri) } \\
\text { kimdir? (Who is TAK Kurdistan Freedom } \\
\text { Hawks?) }\end{array}$ & & $19: 45$ & 7 & 1378 & 1205 & 2583 & \\
\hline $\begin{array}{l}\text { PKK ve devletin çıkmaz yolu (Cul de sac } \\
\text { of PKK and state) }\end{array}$ & Mar 2 & $15: 15$ & 7 & 616 & 283 & 899 & 124 \\
\hline $\begin{array}{l}\text { Cuma Çiçek ile PKK ve devletin çıkmaz } \\
\text { yolu (Cul de sac of PKK and state. With } \\
\text { Cuma Cicek.) }\end{array}$ & & $15: 23$ & 6 & 300 & 418 & 718 & \\
\hline $\begin{array}{l}\text { TAK, dolayısıyla PKK ne yapmak istiyor } \\
\text { (What does TAK (PKK) want to do?) }\end{array}$ & Mar 17 & $15: 30$ & 10 & 1531 & 880 & 2411 & 105 \\
\hline Transatlantik: Gönül Tol \& Ömer Taşpınar & & $17: 00$ & 23 & 849 & 189 & 1038 & \\
\hline
\end{tabular}

Table 1. Five most watched broadcasts of Ruşen Çakır in Feb 16 - March 17, 2016

There were two major terrorist attacks in Ankara in February and March in 2016. The first one on Feb. 17, 2016 targeted the soldiers and 28 people, including 12 soldiers were killed. The second one on March 13, 2016 targeted civilians and 35 people killed. Both attacks were claimed by TAK (Kurdistan Freedom Hawks), an extension of PKK. When looking at Table 1, the major part of the most watched broadcasts consisted of breaking news such as the terrorist attacks. Islamic Movements, Kurdish Issue and terror have been the main subjects on which Çakır delivered his best reports and comments in the years when he was in conventional media.

In Table 1, the broadcast in the list of highest ratings, although its subject was not terrorism, is the special interview with the politician Hüseyin Çelik. Hüseyin Çelik is among the founders of the AK Parti, acted as minister for a long time, took part in the party's governing body, and was spokesman of the party. But later Çelik conflicted with the management and policies of the party and moved away. Therefor he lost visibility in the conventional media.
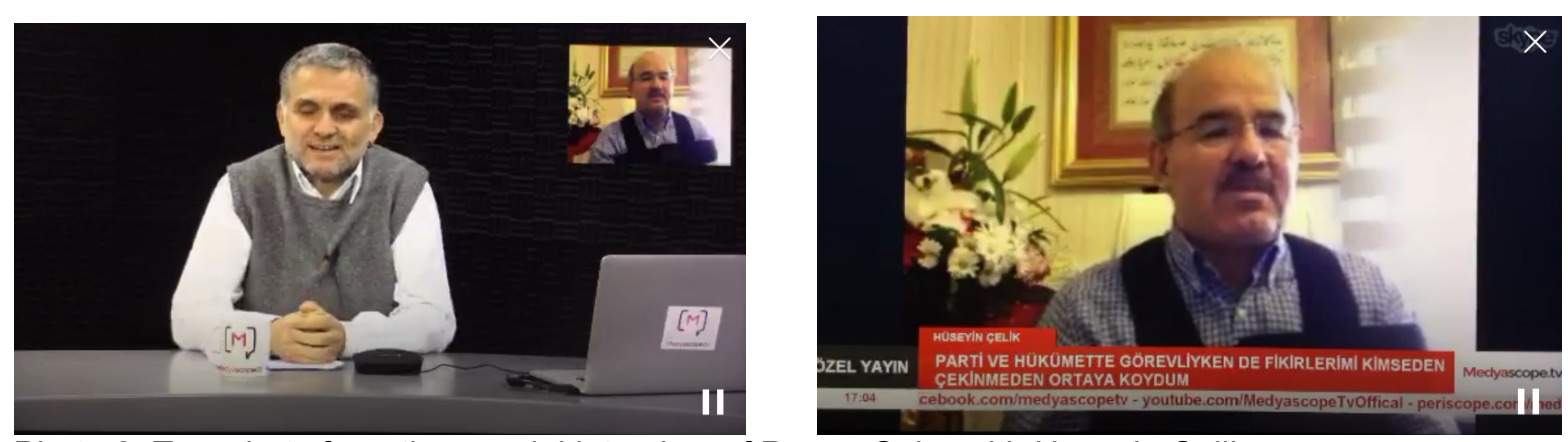

Photo 2. Two shots from the special interview of Ruşen Çakır with Hüseyin Çelik 
The interview of Ruşen Çakır with Hüseyin Çelik on March 82016 continued 48 min and was watched by total 6127 people. Hüseyin Çelik criticized the administration and policies of AK Parti throughout the interview and emphasized that AK Parti should return to its foundation philosophy.

\section{Use of Periscope for Regular Commentaries}

In the sample, the other user, who produces regular content, is journalist Ünsal Ünlü. Ünsal Ünlü delivers two broadcasts every weekday morning. In the first of these broadcasts from his office, he comments on an issue, that he chose, by involving his journalistic experience as a commentator, and in the second broadcast, he reads the front pages of newspapers with the hashtag "what the newspapers wrote and could not write" and comments on the mainstream media's way of handling the agenda in a critical attitude. Periscope broadcasts of Ünsal Ünlü are uploaded on Medyascope.

During the period between Feb 16 - March 17 2016, when the sample had been observed, the total duration of the broadcasts of Ünsal Ünlü was 1303 minutes and these broadcasts were watched by 35944 people, including the live audience and replay audience. The ratings of the broadcasts of Ünsal Ünlü within one month are shown in Graph 2.

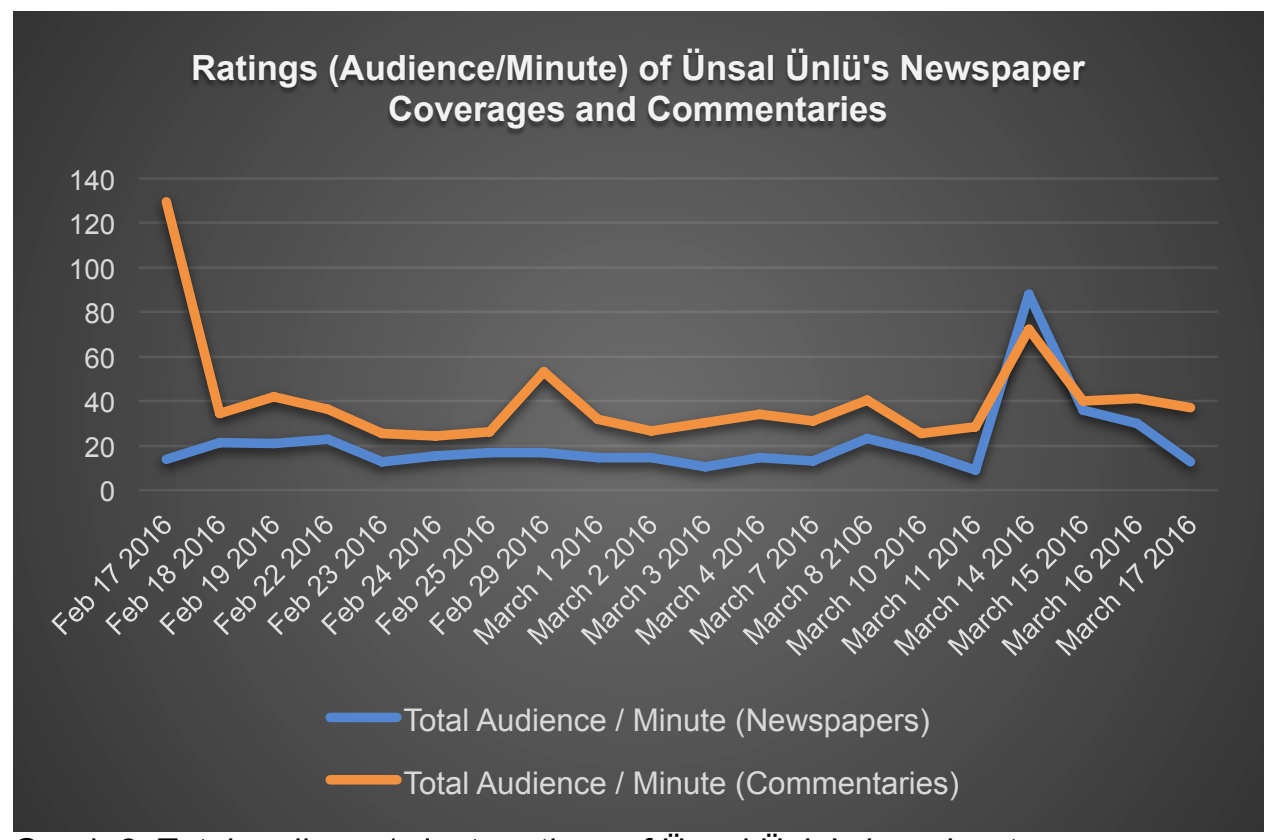

Graph 2. Total audience/minute ratings of Ünsal Ünlü’s broadcasts

Graph 2 shows very clearly that Ünsal Ünlü's commentary broadcasts attract more attention than his broadcasts in which he makes newspaper coverage. Ünsal Ünlü's commentary attracting the highest rating was on Feb. 17, 2016. The total audience/minute value of the broadcast, which was tagged with the title "Those who want to ask the Constitution to the public, must ask Cerattepe as well" was 130 . This number is nearly 5 times more than the average audience/minute value of Ünsal Ünlü being 28 . The subject of the broadcast was the demonstrations of the environmentalists against the copper and gold mine construction in Cerattepe located in Artvin province in the Black Sea region, northeast of Turkey.

The second peak day of Ünsal Ünlü's broadcasts was on March 14, 2016. The two broadcasts on the very next day after the terrorist attack that occurred on March 13 in Ankara and 35 civilians died in, attracted still far above average interest and total 4665 people watched. 


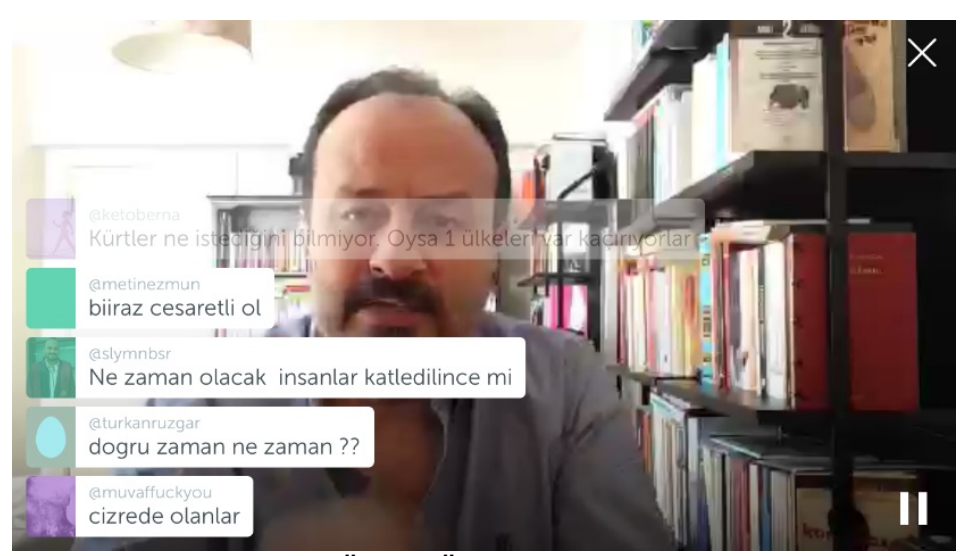

Photo 3. A shot from Ünsal Ünlü's Periscope broadcasts

Ünsal Ünlü announces his broadcasts with newspaper coverage always with the same hashtag: " (What the newspapers wrote and did not (or could not) write). However, he announces his commentaries with different hashtags according to the topics. Among the sample in this research, Ünsal Ünlü is Periscope user, who interacts with the audience the most. During the broadcast, he responds the questions of the audience as much as possible and make them part of this ambient journalism. This makes the audience more willing to act as a participant by asking questions or commenting. But he immediately blocks the senders of messages containing hate, violence, or insults.

\section{Use of Periscope for Behind the Camera}

In the sample, the user, using Periscope as a complementary to his role in conventional media is the anchorman İrfan Değirmenci, who hosted the morning news at Kanal D for many years. İrfan Değirmenci's editor Ertugrul Albayrak provided a view from the back of the studio camera by Periscope broadcast to the audience watching the program through conventional media during TV broadcast. The audience had the possibility to watch what was going on behind the camera in the studio by Periscope while watching İrfan Değirmenci with the images taken by the broadcast camera in the studio. When the live broadcast was paused for ads, the editor went to İran Değirmenci and provided him to interact with his audience.
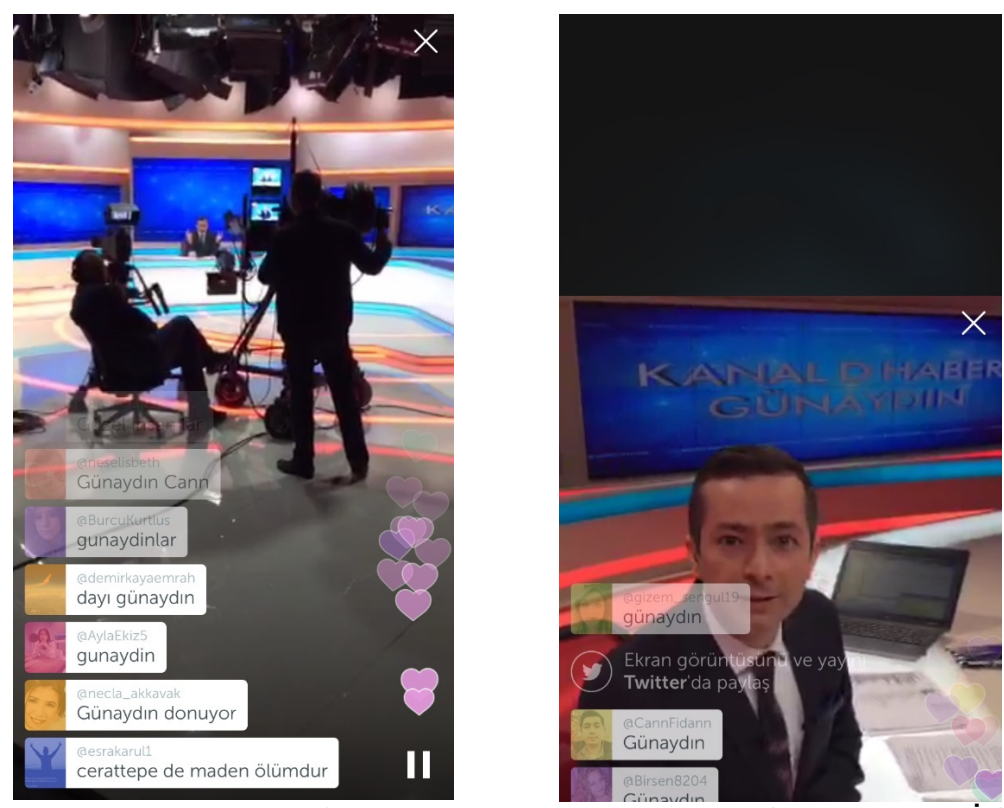

Photo 4. Two shots from Periscope Broadcasts of Anchorman İran Değirmenci

DOI NO: 10.7456/ctc_2017_07

(C) İstanbul Aydın University 
For example, in the broadcast on Feb. 17 2016, while the audience delivered their questions and comments on topics such as public transport fees, fuel prices, the prices of meat, women killings, environmental protests, İran Değirmenci shared his views and answers. So, the broadcast interrupted because of the ads in traditional media, continued on Periscope in new media.

Although İrfan Değirmenci's program is broadcasted every weekday morning, behind the camera was not broadcasted regularly from Periscope. In one-month period, when the observation took place, the Editor broadcasted only 5 times on Periscope. The average audience/minute value of these broadcasts was 59. This number can be assessed as much lower than expected, when considering that it was realized during a mainstream TV with a very high rating. This maybe because the broadcast was not from İrfan Değirmenci's own account but the Editor's.

\section{Use of Periscope for Live Reporting}

For broadcast media, "live from scene" has always been a key element to attract big audiences. The developing technology now does not provide live broadcast opportunity only to broadcast industry but to citizen journalists as well. The biggest attraction offered by a live streaming application like Periscope is the possibility it provides for outside broadcast through just a single touch on a mobile phone (Karadağ, 2017: 713). Certainly, powerful interests still set much of the communication agenda today, and they protect their privileges jealously. But they must do so in a cultural and media environment where anyone with a mobile telephone or tablet computer and an internet connection has the same potential to reach listeners, viewers, and readers as a major television network or political party (Lievrouw, 2011: 214).

Some authors, scholars and bloggers made comparison between live streaming of citizen reporters and live broadcast of professional reporters. One of the comparison criteria is how much of the presented material is news and how much of it is source material. According to Mic Wright, live video of a fire, an explosion or a protest isn't the story, it's a catalyst or source material for a story. It's required to turn this source material into a news story (Wright, 2015). In an article which reports findings from studies regarding the role citizen reporting plays in emergencies, researchers found that citizen reporters were more likely to give voice to alternative sources of information, like bystanders or witnesses of incidents, than sources, such as government representatives. But use of alternative sources does not necessarily translate to providing viewpoints that may contextualize the events (Bal \& Baruh, 2015: 214). For transforming the source material into news and events to be contextualized, the journalistic questions (Who What When Where Why How) must be answered. Any news, which do not answer all of these six questions cannot be said to in integrity. Because delivering a news is not just defining an action, a discourse or an action-discourse only in its accurate and verified form but defining also a series of contextual criterion which make the target audients comprehend the deep meaning of that event (Ramonet as cited in Girgin \& Özay, 2013: 64).

Like above mentioned criteria for the news in conventional media, there are professional codes for live reporting, too. There are several things to do before a reporter steps in front of the camera. The first step is to really know the story - understand it, including any implications it has or change it may cause (Stephenson et al., 2005: 171). Reporters who cover breaking news live must have knowledge of many subjects, be in control of their emotions, and must be able to ad-lib fluently and informatively (Hyde \& Ibrahim, 2009: 169). Reporter's ability to ad-lib an unfolding news event in an accurate, effective manner is essential for success in live reporting (Hyde \& Ibrahim, 2009: 165). Reporters should describe not only the events but also the environment. They can include sounds, smells, people's reactions, efforts to deal with the situation, and things that are changing (Stephenson et al., 2005: 171) Even detailed live reporting codes for specifically subject-based or for difficult situations have been created. For example, there are "extensive and detailed topics such as "Riots and demonstrations", "Hijacking and hostage taking", "Use of material from racist, violent or illegal organizations", "Suicide", "Bomb threats", "Form of report on controversial subjects" available at CBC Radio-Canada's Live Reporting Principles (CBC Radio-Canada Live Reporting Principles). 
Of course, the citizen reporter should not be expected to broadcast in line with codes so much advanced and described in details, at least for the moment. But the citizen reporters improve their journalism practice and those who study for them develop more qualified new media codes for live reporting. For example, Adornato recommends live streamers the following:

\begin{abstract}
Streaming video through Facebook Live or Periscope can bring people to the scene in ways other social media posts can't. There should be a reason why you're live-streaming though. Don't simply use technology for technology's sake. Tell people what they're looking at, and provide a recap periodically, as new people will continue to join the stream. Use your ethical judgment when deciding what to stream. In dangerous or unfolding situations, be mindful that you could broadcast a worst possible scenario. (Adornato, 2017: Kindle Locations 2325-2328).
\end{abstract}

During the period of observation in the sample, the citizen journalism account, from which the most live streaming was Çapul TV (@capul_tv). Çapul TV is a citizen reporting channel, created by citizens, who found that the coverage of the media during the Gezi Park protests were insufficient or incorrect. After the Gezi protests, they continued citizen reporting on various social and environmental issues.

During the period of observation, Çapul TV had 13 broadcasts. These broadcasts lasting total 160 minutes were watched by 26796 people and the total audience/minute value was 167 . The ratings of the broadcasts of Çapul TV are shown in the Graph 3.

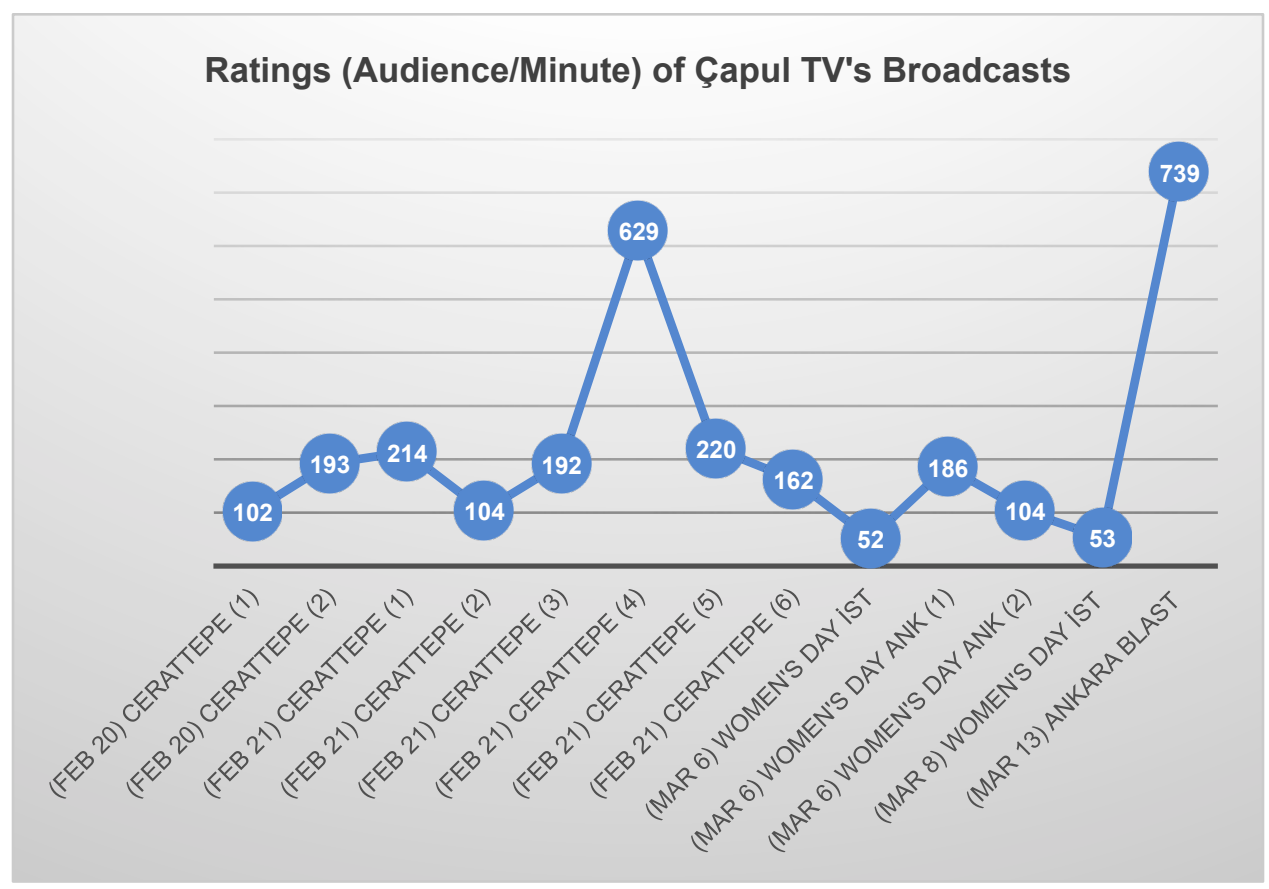

Graph 3. Total audience/minute numbers of Çapul TV broadcasts

When looking at the Graph 3, it can be seen that the highest rating for the Çapul TV broadcast was on March 13, 2016. While the average audience/minute of Çapul TV was 167, it reached 739 with the broadcast on March 13, 2016, that is about 4.5 times the average rating. Çapul TV delivered this broadcast around 1 hour later than the blast in Ankara Kızılay and tagged with "We are close to the blasting point in Ankara." When looking at graph 3 another peak broadcast was on Feb 21, 2016. It was a broadcast about Cerattepe. The broadcast with the highest rating of Çapul TV are shown in Table 2. 
Table 2. Most Watched Broadcasts of Çapul TV in Feb 16 - March 17, 2016

\begin{tabular}{|l|c|c|c|c|c|c|c|}
\hline Name of Broadcast & Date & Time & Dur & $\begin{array}{c}\text { Live } \\
\text { Aud }\end{array}$ & $\begin{array}{c}\text { Replay } \\
\text { Aud }\end{array}$ & $\begin{array}{c}\text { Total } \\
\text { Aud }\end{array}$ & $\begin{array}{c}\text { Total } \\
\text { Aud/Minute }\end{array}$ \\
\hline $\begin{array}{l}\text { \#Ankara patlama noktasının } \\
\text { yakinindayız (We are close to } \\
\text { blasting point in Ankara) }\end{array}$ & Mar 13 & $19: 50$ & 3 & 1213 & 1004 & 2217 & 739 \\
\hline $\begin{array}{l}\text { Cerattepe eylemi acil destek } \\
\text { (Cerattepe protest emergent support) }\end{array}$ & Feb 21 & $13: 51$ & 4 & 1824 & 691 & 2515 & 629 \\
\hline Artvin Cerattepe & Feb 21 & $13: 57$ & 7 & 1227 & 315 & 1542 & 220 \\
\hline $\begin{array}{l}\text { Artvin Cerattepe Eylemi (Artvin } \\
\text { Cerattepe protest) }\end{array}$ & Feb 21 & $12: 05$ & 8 & 1505 & 205 & 1710 & 214 \\
\hline $\begin{array}{l}\text { Artvin Cerattepe Maden Eylemi } \\
\text { (Artvin Cerattepe Protest for Mining) }\end{array}$ & Feb 20 & $13: 16$ & 38 & 6792 & 542 & 7334 & 193 \\
\hline $\begin{array}{l}\text { Artvin Cerattepe maden eylemi } \\
\text { (Artvin Cerattepe Protest for Mining) }\end{array}$ & Feb 21 & $12: 50$ & 10 & 1695 & 221 & 1916 & 192 \\
\hline
\end{tabular}

Çapul TV delivered 4 broadcasts on Feb 21, 2016 from Cerattepe. But one of them had much more rating than the other three. The reason for this may be form of tagging the broadcast. While the other three were tagged as "Artvin Cerattepe protest for mining", the broadcast with the highest rating had been tagged much more strikingly, "Cerattepe protest emergent support".
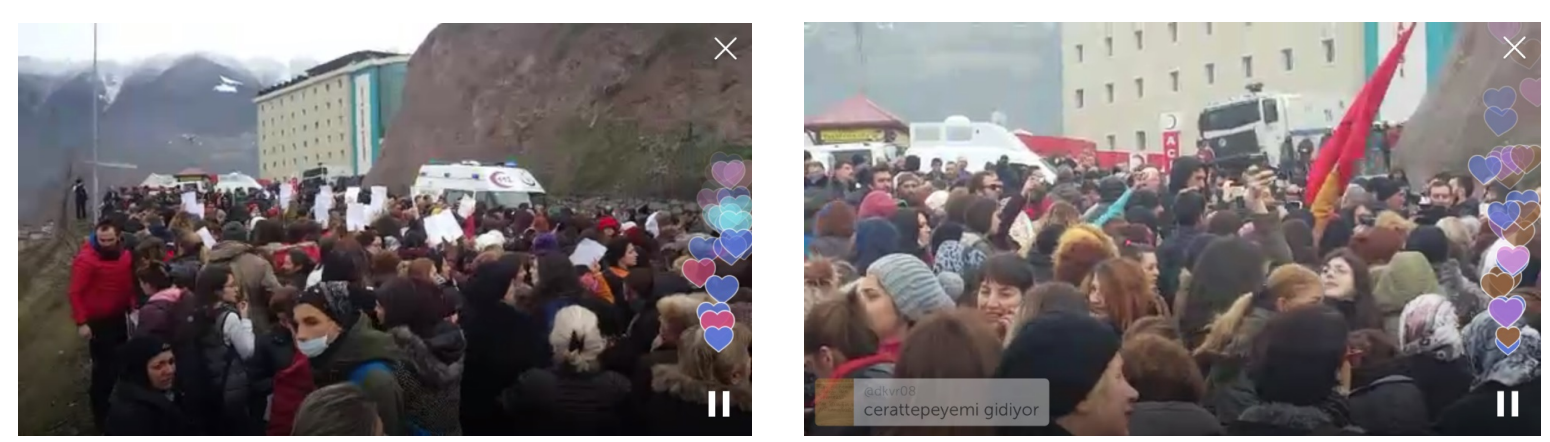

Photo 5. Two shots from Cerattepe broadcasts

In all of the Cerattepe broadcasts, activist reporting was performed. The citizen journalist who delivered the live reporting was narrating what was going on one hand, and invited to share it on Twitter to make more people to watch the broadcast on the other hand. He replied some tweets saying, "You are terrorists," by saying "We are not terrorists, we defend our right to live." He frequently highlighted that the police protected the rich instead of people.

The citizen journalist of Çapul TV reporting from Women's Day Manifest in Ankara performed nearly as good as a professional journalist. The broadcast consisted of the answers of journalistic questions. The citizen reporter did not behave like an activist, but kept more in an objective position. In order to make the audience comprehend what was going on, he used descriptive statements and presented background information. For those who just started to watch the broadcast, he had frequently repeated the covered event, and where it was. When ending a broadcast once, he even said "Now a short break, we're back very soon". Below, you can see the narration of that broadcast: 

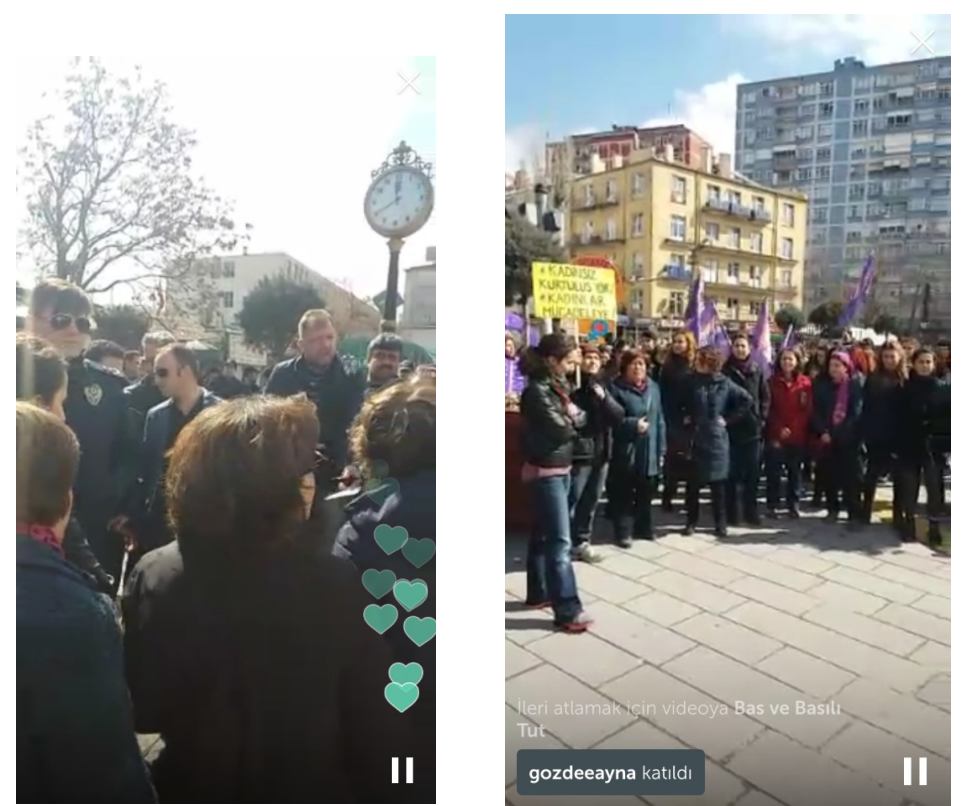

Photo 6. Two shots from Ankara Women's Day broadcasts

(Broadcast starts)

(A dialogue between the female demonstrators and the police)

Policeman: What's your program?

Spokeswoman: We will walk as usual.

Policeman: No walking)

\section{Citizen Reporter:}

Currently we are at Kolej Square in Ankara.

Women gathered for the event of March 8, but the police do not permit the women to gather.

Talks with the police go on.

The women gather at Kolej Square in Ankara to celebrate March 8 upon the call of Women's Platform for 10 years.

This is one of them.

A policeman says, "We have the Governor's order, don't wait here, move along."

A spokeswoman says, "We are using our constitutional rights, this order is illegal."

Women say, "We walked here four months ago, what has changed?"

(The police make an announcement)

"Action is prohibited by the Governor.

If you don't leave now, you will be expelled away from this area by using proportional power.")

\section{Citizen Reporter:}

Currently the police announcement continues.

We are at Kolej Square in Ankara.

The women celebrate March 8 by gathering at Kolej square and marching towards Ziya Gökalp for 10 years.

This year, the Governor's Office did not allow women to celebrate March 8 here.

Now they announce to women.

Women respond with slogans and songs to police. 
(Reporter keeps silent for a while)

Citizen Reporter:

The women continue to come to Kolej square.

The women say that they will be in the field for March 8 despite prohibitions.

Talks continue with the police.

Policeman: Walk individually on sidewalk.

\section{Citizen Reporter:}

Yes, currently the women continue to come.

As you can see, the women do not obey the prohibition.

There has been a short squabble near the police barricade because the women are not allowed to pass to the square.

Rally continues.

Minor clashes with the police happening.

The women insist on entering the field where they gathered for 10 years.

Entry in the field continues with chanted slogans.

We are at Ankara Kolej Square.

On one side they continue to gather while they say that they will walk no matter what happens.

They are committed to enter the field.

Now we take a short break on the air.

We're going to start again later.

\section{Use of Periscope for Breaking News Coverage}

"When something newsworthy is happening where it is unexpected,the odds that a professional journalist holding a camera or video camera are small. But the odds that a regular person will be there are close to 100 percent." (Lever, 2015). Dan Gillmor mentioned this fact in an interview with AFP (Agence France Presse). The scenario, where Periscope, enabling to broadcast through a mobile application from anywhere having cellular accession by a single touch would be the most effective, is in a case of shocking breaking news a citizen broadcasts from the scene. One such example occurred in the observation period. On March 13 in 2016 a car bomb exploded in Ankara Kızılay and 37 people were killed in this terrorist attack targeting civilians. The attack occurred at 18.40 and 10 minutes later at 18.50 a young citizen nearby started broadcasting through Periscope. The only thing that user, whose name was not heard at all, was being there at that moment and touching Periscope application. In fact, even his user name, meant nothing: Jhgguu. But 10 minutes broadcast was watched by 28232 people. Whereas there were only 516 followers of his Periscope account. The audience/minute value of that broadcast was 2823 . The average audience/minute value of all broadcasts in the sample was only 88 .

Graph 4. Comparison of the rating of citizen coverage of Ankara Kızılay Blast with the average rating of the sample.

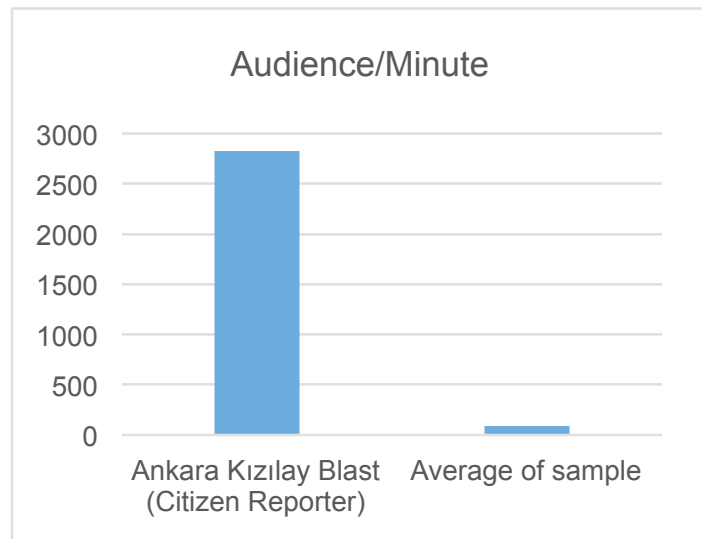

DOI NO: 10.7456/ctc 2017 07 
The user Jhgguu, heard the explosion in Kızılay from Sıhhiye, less than a kilometer away from there. As soon as heard it, he started the Periscope application and started walking towards the place where it happened. While walking, he was recording the surrounding and informing the audience as much as he could. He was telling that people were moving away, and there were glass pieces on the ground. The windows of the shops nearby were broken because of the explosion. Breaking of the windows hundreds of meters away was giving clues about the severity of the explosion. When he was close to the scene, he looked for a witness and found one. He asked what the witness saw, heard and felt. The witness could tell very little, but ultimately a citizen tried to cover a breaking news by performing both live reporting and interview. In the meantime, the audience were asking questions on the one hand and giving information on the other hand.
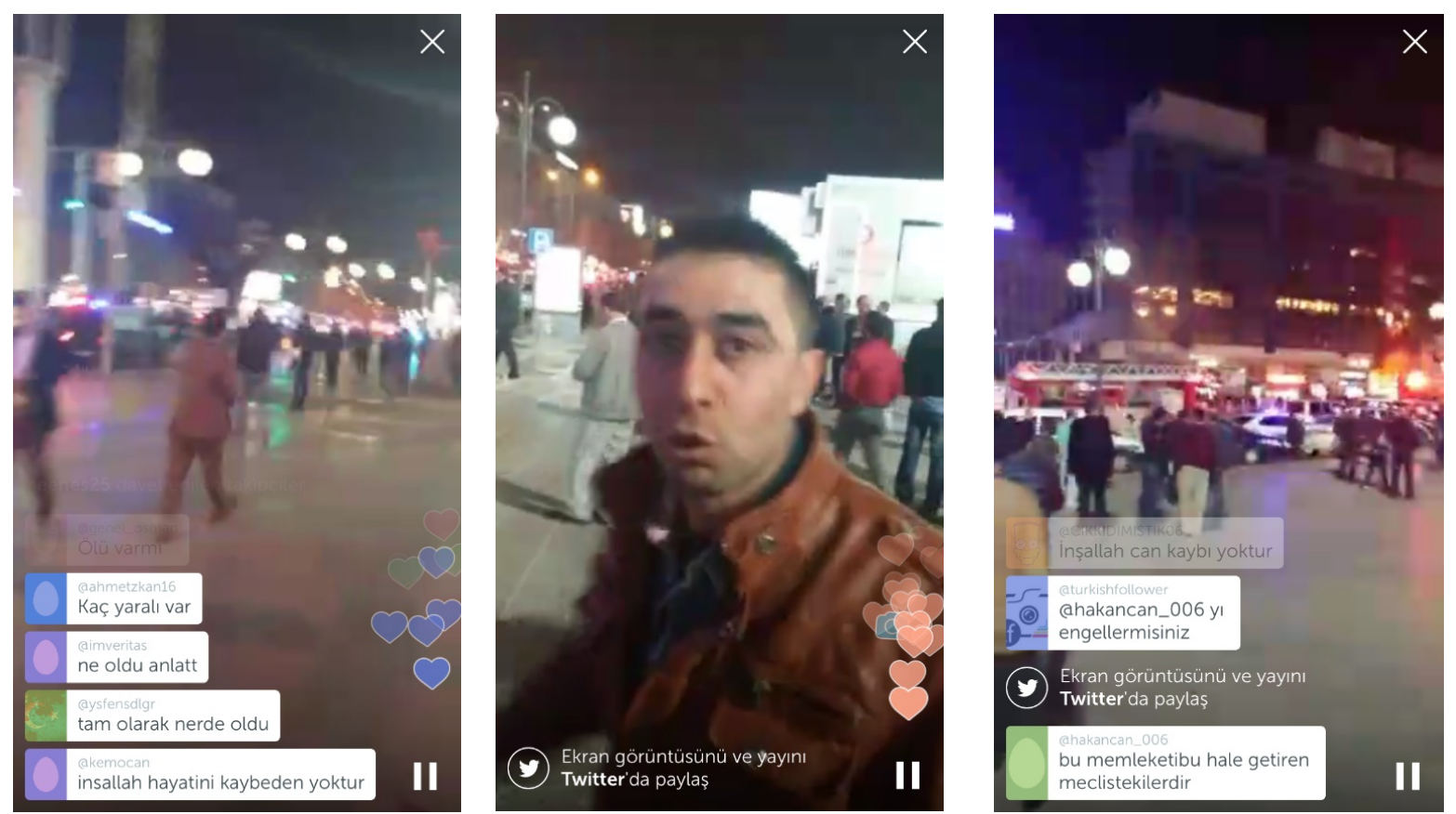

Photo 7. Three shots from Ankara Kızılay blast broadcast.

The audience comments and questions readable in the shots in Photo 7 are as follows: "Tell what happened" / "Where exactly did it happen?" / "I hope there is no one who lost their lives." / "It was heard in Ümitköy" / "Any dead?" / "It was heard in Dikmen." / "There were two bombs, be careful!"

So, the audience were both directing the citizen reporter and giving him information. Of course, the reliability of such information supplied immediately after the event there and then was very questionable but the audience writing that the explosion was heard in Dikmen and Umitkoy helped at least to have an idea about the severity of the explosion. However, it was not possible for the reporter to answer the questions such as "How many injured?" or "Where did it exactly happen?" at that moment and at that point.

Citizen reporter headed for the place where the explosion had happened but could not go beyond a certain point because of the police security circle. Fire trucks, ambulances, police vehicles came into vision from far, sirens were heard. Citizen reporter ended the 10-minute broadcast.

\section{Conclusion}

Live broadcast, being in the monopoly of the conventional media in the past, has become a broadcasting opportunity accessible to much more people thanks to the developing digital technology. This opportunity is even available to anybody using a cellular phone through applications that make live streaming possible by a single touch. Periscope, which is a mobile live streaming application, is one of 
them. This study aims to identify, classify and reveal the properties of various reporting and interviewing styles in the new media by conducting the quantitative, qualitative, and discourse analysis of the live streaming of the professional and citizen reporters on Periscope. Thus, also the answer to the question, whether the content produced on Periscope is in compliance with the format of that medium is investigated. In the present study, it has been questioned what the data at hand points for facilitating the professionals, who use Periscope independently from their roles within the conventional media or as a complementary to their roles in the conventional media and the citizens, who use it for journalistic purposes to create an effective alternative in this new platform.

A sample composing of 40 professional and citizen reporter accounts was created and 121 broadcasts by these users in a one-month period (Feb 16 - March 17, 2016) were included in the research. The broadcasts in the sample have been reviewed both in terms of reporting and interviewing styles. As a result of the review, the usage types of the professionals and citizens have been classified as follows:

- Use of Periscope for regular studio interviews

- Use of Periscope for regular commentaries

- Use of Periscope for behind the camera

- Use of Periscope for live reporting

- Use of Periscope for breaking news coverage

The qualitative or quantitative potential of these different reporting and interviewing styles are different. For example, when focusing on the numbers, use of Periscope for breaking news coverage has an undisputed advantage in terms of attracting the audience. The audience/minute value of citizen's broadcast covering Ankara Kızılay Blast going over 32 times more than the sample's average shows very strikingly how an attractive new media application could Periscope be especially for such situations. Moreover, in this broadcast, the citizen did not only display what was happening but also helped the audience to better grip the event by performing live stand-up.

The second most-watched category in the above classification has been the use of Periscope for live reporting. In this category, mainly the protests and demonstrations not sufficiently covered by the mainstream media have been broadcasted by citizen reporters on Periscope as they unfold. In these broadcasts, both activist reporting examples and very nearly professional reporting examples have been observed. Answering the journalistic questions $(5 \mathrm{~W} 1 \mathrm{H})$ in a live reporting, keeping an objective position, using descriptive phrases, providing background information, providing reminders for new comers etc., which would be expected from professional reporters, could be exhibited also by citizen reporters.

Despite of attracting less audience than using Periscope for live reporting, another broadcasting category, actually having a serious potential is using Periscope for behind the camera. In the research sample, as an instance for using Periscope for behind the camera, the broadcasts of İrfan Değirmenci, the host of morning news in Kanal D has been reviewed. Thanks to these broadcasts, Irfan Değirmenci created and interaction with the audience, which would not be possible with the conventional media. However, this interaction could be drawn to much more advanced levels (from carrying out questionnaires to sharing a striking information about the background of a news or to a more specific hashtag) and the attraction of behind the camera broadcast can be increased. Of course, this is a matter of the corporate view of the channel employing the anchorman and how far they permit.

The most effective instances of the category of using Periscope for regular studio interviews in this sample consisted of the broadcasts of journalist Ruşen Cakır. However, those broadcasts are rather in the old media format than the new media format. Considering that the videos in the new media are watched more in mobile viewing and the short form videos are viewed rather than the long form, it can be concluded that audience potential of old media format broadcast will be lower. Indeed, this was the case in this sample. However, Ruşen Çakır's broadcasts are important because of bringing up issues not handled by the mainstream media (or even if handled, then the questions not being asked) and guests unable to show 
up in the mainstream media into agenda. In addition, regular content production is a major issue in the new media per se.

Another name producing regular content in the sample is journalist Ünsal Ünlü. He is using Periscope for regular commentaries. In the first of these broadcasts from his office, he comments on an issue that he chose, by involving his journalistic experience as a commentator, and in the second broadcast, he reads the front pages of newspapers and comments on the mainstream media's way of handling the agenda in a critical attitude. Nevertheless, because of being a single commentary, he obtains relatively low audience/minute values within the research sample. But like Ruşen Çakır, Ünlü produces very important contents in the sense of creating alternatives to mainstream media too. Moreover, even though his broadcasting seems to be single commentary, actually it creates a collective content together with the audience. Ünsal Ünlü is the Periscope user interacting the most with the audience within the sample of this research. He answers the questions of the audience as much as possible during the broadcast and makes them a part of this ambient journalism.

People describing Twitter as a revolution for citizen journalism saw Periscope as a form of revolutionary Twitter with an additional live-video coverage and attributed bigger roles to it in the context of new media, social media and alternative media. However, when the use of Periscope both by the professional and citizen reporters is considered, it can be seen that it does not create such a strong influence like Twitter. Whereas, an application, providing anyone having a smart phone and internet connection, the possibility of live streaming just by one click has a great potential for both citizen reporters and professional reporters. But it is crucial for the content produced for new media to meet the new media format in order to activate the potential offered by new media. Continuing the qualitative, quantitative analyses of the reporting and interviewing styles in the new media and the impact of them will provide important data for the evaluation of the potential offered by new media.

\section{References}

[1] Adornato, A. C. (2017). Mobile and Social Media Journalism: A Practical Guide. SAGE Publications. Kindle Edition.

[2] Bal,H. M. \& Lemi, B. (2015). Citizen involvement in emergency reporting: A study on witnessing and citizen journalism. Interactions: Studies in Communication \& Culture. Volume 6, Issue 2. pp. 213-232. DOI: 10.1386/iscc.6.2.213_1.

[3] Binark, M. (Ed.) (2014). Yeni Medya Çalışmalarında Araştırma Yöntem ve Teknikleri. İstanbul: Ayrıntı Yayınları.

[4] Binark, M. (2015). Yeni Medya Çalışmaları Özel Sayısı Hakkında? Neden? Folklor/ Edebiyat. Volume 21, Issue 83. pp. 9-18.

[5] CBC Radio-Canada Live Principles http://www.cbc.radio-canada.ca/en/reporting-to-canadians/acts-and-policies/programming/journali sm/live-reporting/

[6] Dahlgren, P. (1996). Media Logic in Cyberspace: Repositioning Journalism and its Publics. Journalism at the Crossroads. Volume 3, No 3. pp. 59-72.

[7] Deuze M. (2004). What is multimedia journalism? Journalism Studies. Volume 7, Issue 2. pp. 139-152. DOI: 10.1080/1461670042000211131

[8] Girgin A. \& Özay S. (2013). Haber Yazmak. DER Yayınları: İstanbul.

[9] Godkin, P. (2008). Rethinking Journalism as a Profession. Canadian Journal of Media Studies. Volume 4, Issue 1. pp. 109-121.

[10] Hermida, A. (2010). From TV to Twitter: How Ambient News Became Ambient Journalism. M/C $\begin{array}{lllll}\text { Journal, } & \text { Volume } & 13, & \text { Issue } & \text { Retrieved }\end{array}$ from http://journal.media-culture.org.au/index.php/mcjournal/article/view/220

[11] Hyde, S. \& Ibrahim, D.A. (2009). Television and Radio Announcing. Routledge: New York.

[12] IPI Q\&A with Ruşen Çakır of Turkey's Medyascope.tv. International Press Institute. https://ipi.media/ipi-qa-with-rusen-cakir-of-turkeys-medyascope-tv/ March 1, 2016. 
[13] Jenkins, H. (2008, May 9). From Production to Produsage: Interview with Axel Bruns (Part One) http://henryjenkins.org/blog/2008/05/interview_with_axel_bruns.html

[14] Karadağ, G.H. (2017). What Does Periscope offer to Professional and Citizen Reporters? A Sample Study from Turkey. The Turkish Online Journal of Design, Art and Communication TOJDAC Volume 7. Issue 4. DOI: 10.7456/10704100/016 (709-727).

[15] Karhunen, P. (2017). Closer to the Story? Accessibility and Mobile Journalism. Reuters Institute Fellowship Paper. University of Oxford. July 2017.

[16] Lever, R. (2015, March 29). New Streaming Apps Could Boost Journalism. AFP. Retrieved from http://news.yahoo.com/streaming-apps-could-boost-citizen-journalism-041709105.html

[17] Lievrouw, L.A. (2011). Alternative and Activist New Media. Polity Press: Cambridge.

[18] Morgan V. (2008). Practising Videojourmalism. Routledge: New York.

[19] Pearce, D. (2015, March 26). Twitter's Periscope App Lets You Livestream Your World. Wired. Retrieved from http://www.wired.com/2015/03/periscope/

[20] Pavlik J. (2000). The Impact of Technology on Journalism. Journalism Studies. Volume 1, Issue 2. pp. 229-237. DOI: 10.1080/14616700050028226.

[21] Reid, Alastair (March 26, 2016). 5 Livestreaming Apps for Journalists and Newsrooms. Journalism.co.uk. Retrieved from https://www.journalism.co.uk/news/5-livestreaming-apps-forjournalists-and-newsrooms/s2/a56459 7/ e.t. April 15, 2017

[22] Rosen, J. (2011). The People Formerly Known as the Audience http://www.huffingtonpost.com/jay-rosen/the-people-formerly-known_1_b_24113.html Updated May 25, 2011.

[23] Stephenson, A.R. \& Reese, D. E. \& Beadle M. E. (2005). Broadcast Announcing Worktext. Focal Press: Burlington.

[24] Şahin, M. \& Şahin, G. (2016). Geleneksel Medyanın Yeni Rakibi: Yeni Medya ve Canlı Yayınlar. Yeni Medya. Volume: 2016/Fall Issue: 1.

[25] Ünal, R. (2017). Yeni Medyada Yeni Habercilik ve İş Modeli Arayışları: Medyascope Örneği. Galatasaray Üniversitesi İleti-ş-im Dergisi, 26, 83-107. DOI: 10.16878/gsuilet.324206.

[26] Wright, Mic (2105, March 30). Periscope Won't Change the World but It Appeals to Journalists' Vanity. TNW. http://thenextweb.com/opinion/2015/03/30/roll-up-roll-up-to-see-theomnibang/\#gref

[27] Yengin D. (2014). Yeni Medya ve Dokunmatik Toplum. Derin Yayınları: İstanbul.

DOI NO: 10.7456/ctc_2017_07

(C) İstanbul Aydın University 